\title{
MENERAPKAN METODE SNOWBALL THROWING UNTUK MENINGKATKAN KEMAMPUAN MEMBACA PEMAHAMAN SISWA KELAS VII-E SMPN 3 WARU
}

\author{
Linda Anisa, Retno Danu Rusmawati \\ Program StudiPendidikan Bahasa dan Sastra Indonesia. Fakultas Keguruan dan Ilmu \\ Pendidikan, Universitas PGRI Adi Buana Surabaya \\ lindaanisaprempuan92@gmail.com, pambayun61@gmail.com
}

\begin{abstract}
The subject of this research was the seventh grade students 2014/2015 academic year. The number of participants in this research was 36 students, there are 16 boy students and 20 girl students. In completing the research, the researcher used the observation,teacher and students activity, written test and field note as the instruments of collecting the data. The result of this research on pre-cycle or first reading skill comprehension condition of students acquire three students can be done with $8,32 \%$ on the class that consist 50,05 . On the second cycle in the teacher activity was 83,3\%; and students activity was showed 85,4\%; the result test of students reading skill comprehension was $27,78 \%$ and the average was 74,78 . The second cycle result was $16,7 \%$ which is higher than first cycle. In the teaching activity that shows has improved about $6,96 \%$ to $92,36 \%$; the result of reading skill comprehension test based on SKL was 94,44\% improve about $66,66 \%$. In other hand, the average of study reading skill comprehension higher than before was $9,41 \%$ improve to 84,19 . This research was improving students reading skill of Junior High School 3 Waru. Through reading comprehension, students were indirectly recognize and memorize learning material.
\end{abstract}

Keyword: Reading Skill, Comprehension, Snowball Throwing

\section{PENDAHULUAN}

Pada kurikulum 2013 peserta didik dituntut lebih aktif berpikir kritis dan lebih meningkatkan pemahaman semua mata pelajaran, khususnya bahasa Indonesia. Kenyataan di lapangan yang penulis temui setelah melakukan observasi, bahwa peserta didik kurang memahami suatu cerita atau sebuah paragraf yang telah disiapkan oleh guru. Dari permasalahan tersebut penulis mencoba melakukan penelitian terhadap permasalahan yang ada di kelas.

Berdasarkan hasil observasi peneliti dengan guru mata pelajaran Bahasa Indonesia SMPN 3 Waru Sidoarjo yakni Ibu Katmiati, S.Pd diperoleh informasi bahwa kelas VII-E untuk kemampuan membaca dan memahami bacaan siswa yang masih rendah. Terutama membaca pemahaman siswa menjadi permasalahan yang akan peneliti kaji. Hasil diskusi peneliti dengan guru bahasa Indonesia SMPN 3 Waru Kab.Sidoarjo disepakati untuk mengatasi problem tersebut dilakukan penelitian tindakan kelas dengan metode pembelajaran yang menarik. Adapun upaya pemecahan masalah yang terkait dengan kemampuan menulis siswa yaitu penerapan metode pembelajaran Snowball Throwing.

Menurut Nurhadi (2010: 31) kecepatan yang memadai dan presentase pemahaman yang tinggi. Dua aspek inilah yang menjadi kunci jenis membaca pemahaman. Ada beberapa langkah yang dapat dilakukan dalam membaca 
pemahaman, antara lain: (1) Membaca teks secara berulang-ulang; (2) Menuliskan kembali hal-hal yang dianggap penting; (3) Membuat kesimpulan tentang isi teks. Merespon atau mempraktekan isi bacaan, dalam hal ini menyeleksi bacaan. Membaca pemahaman menurut Webster Collegiate Dictionary menawarkan definisi ini: "kapasitas pemikiran untuk memahami dan mengerti". Membaca pemahaman, maka, akan menjadi kapasitas untuk menerima dan memahami makna yang disampaikan oleh teks. Rubin (1993: 194) mendefinisikan bahwa membaca pemahaman adalah proses pemikiran yang kompleks untuk membangun sejumlah pengetahuan.

Menurut Huda (2013: 226) Snowball Throwing (ST) atau yang sering dikenal dengan Snowball Fight yang diadopsi pertama kali dari game fisik di mana segumpalan salju dilempar dengan maksud memukul orang lain. Dalam konteks pembelajaran ini, diterapkan dengan melempar segumpalan kertas untuk menunjuk siswa yang diharuskan menjawab soal dari guru. Strategi ini digunakan untuk memberikan konsep pemahaman materi yang sulit kepada siswa serta dapat digunakan untuk mengetahui sejauh mana pengetahuan dan kemampuan siswa dalam materi tersebut.

Berhubungan dengan paparan di atas, penelitian ini ingin menjawab pertanyaan, apakah metode Snowball Throwing dapat meningkatkan kemampuan membaca pemahaman siswa kelas VII-E SMP Negeri 3 Waru? yang hasilnya dapat bermanfaat dan diharapkan dapat dijadikan bahan masukan bagi pengembangan pengetahuan yang berkaitan dengan pemantapan dalam pembelajaran membaca. Serta bagi guru dapat digunakan sebagai salah satu masukkan dalam mengajar mata pelajaran bahasa Indonesia. Hasil penelitian ini memberikan kesempatan bagi guru untuk mengetahui metode dan teknik mengajar yang efektif, inovatif dan menyenangkan sehingga meningkatkan kemampuan membaca efektif yang dapat menyenangkan bagi siswa. Menurut Asrori (2010), tujuan pembelajaran Snowball Throwing yaitu melatih siswa untuk mendengarkan pendapat orang lain, melatih kreatifitas dan imajinasi siswa dalam membuat pertanyaan, serta memacu siswa untuk bekerjasama, saling membantu, serta aktif dalam pembelajaran.

Dengan demikian penelitian bertujuan meningkatkan kemampuan membaca pemahaman siswa kelas VII-E SMP Negeri 3 Waru melalui penerapan metode Snowball Throwing.

\section{METODE PENELITIAN}

Subjek penelitian ini adalah siswa kelas VII-E SMP Negeri 3 Waru tahun ajaran 2014/2015. Jumlah siswa dalam satu kelas sebanyak 36 siswa yang terdiri atas 16 laki-laki dan 20 siswa perempuan. Kegiatan evaluasi/observasi dilakukan oleh peneliti sesuai dengan melakukan pengamatan. Observasi dilakukan oleh guru ketika siswa dalam berproses. Terutama pada aktivitas praktik membaca efektif dan seberapa besar tingkat pemahaman siswa pada teks yang dibaca. Observasi dilakukan dengan menggunakan lembar observasi dan juga rubrik penilaian untuk pedoman menilai.

Data yang diperoleh dari hasil pengamatan tentang aktivitas guru dan kemampuan membaca efektif selama 4 pertemuan dan lama penelitian 40/pertemuan, serta seberapa besar tingkat pemahaman siswa pada teks yang dibaca. Berdasarkan analisis akan diperoleh aktivitas guru saat melaksanaan 
tindakan di kelas dan juga kemampuan siswa dalam menulis teks tanggapan deskriptif. Teknik pengumpulan data yang dilakukan adalah praktik membaca pemahaman, menjawab pertanyaan yang telah dibuat oleh teman yang telah dibaca bersama-sama dan observasi penerapan tindakan metode pembelajaran yang dilakukan oleh guru pada proses pembelajaran. Teknik yang digunakan dalam penelitian ini adalah teknik tes dalam penelitian pendidikan.

Analisis data pada penelitian ini dilakukan dengan menggunakan teknik deskriptif dan statistik deskriptif dan hasilnya berupa grafik yang menerangkan nilai yang diperoleh siswa setelah dilaksanakan tes. Pada teknik deskriptif ini, peneliti menggambarkan aktivitas guru berada di kelas saat proses pembelajaran dan juga aktivitas siswa saat melakukan praktik membaca pemahaman dan menjawab pertanyaan yang telah dibuat oleh teman menggunakan metode Snowball Throwing. Analisis menggunakan perhiungan persentase (\%) dengan menghitung banyaknya frekuensi yang muncul selama pembelajaran berlangsung dengan aktivitas keseluruhan dikali 100\%. Dalam teknis analisis ini menggunakan perhitungan persentase keberhasilan siswa dalam mengusai materi.

\section{HASIL PENELITIAN}

Hasil penelitian yang bertujuan untuk meningkatkan kemampuan membaca pemahaman pebelajar melalui metode Snowball Throwing yang mana dalam siklus I belum terlihat ketuntusan pebelajar, maka dilaksanakan kembali dalam siklus II untuk mencapai standart kompetensi lulusan (SKL) sebesar 80.

Pada grafik 1 di bawah ini menjelaskan pada siklus I nilai yang didapat belum memuaskan. Pada grafik warna orange menunjukkan pebelajar yang tuntas atau mencapai SKL hanya 10 pebelajar dengan persentase $27,78 \%$, grafik warna kuning menunjukkan pebelajar yang belum tuntas atau belum mencapai SKL sebanyak 26 pebelajar dengan persentase $72,77 \%$, dan grafik warna hijau menunjukkan nilai rata-rata kelas sebesar 74,78.

Garfik 1. Hasil Tes Pebelajar VII-E SMPN 3 Waru pada Siklus I

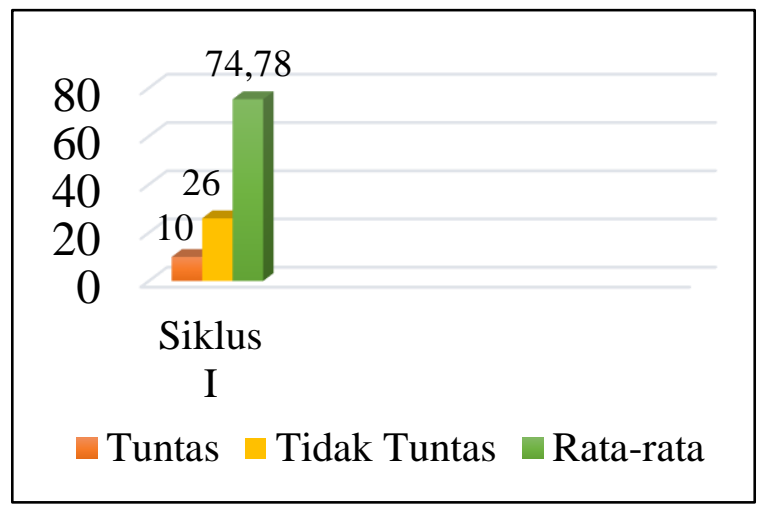

Grafik di atas menunjukkan bahwa tingkat ketuntasan masih rendah, oleh karena itu tingkat keberhasilan siswa $\geq 80$ diperoleh 10 siswa dengan persentase $27,78 \%$ dan tingkat keberhasilan siswa $\leq 80$ diperoleh 33 siswa dengan persentase $72,22 \%$.

Berbagai hambatan atau kelemahan yang di jumpai di siklus I, maka untuk memasuki siklus II diadakan perbaikan untuk mengatasi kelemahan yang terjadi 
pada siklus I, sehingga pada silkus II kemampuan membaca pemahaman pembelajar dapat mengalami peningkatan.

Beberapa hal yang dilakukan oleh peneliti untuk mengatasi permasalahan yang di jumpai pada siklus I antara lain:

1) Menambah pertanyaan yang semula pebelajar membuat pertanyaan sendiri sejumlah satu, akan ditambah tiga pertanyaan;

2) Pembelajar memberi motivasi pada pebelajar agar ketika mempresentasikan hasil kerjanya pebelajar siap dan hasilnya memuaskan.

3) Meningkatkan pengawasan dalam membaca pemahaman agar proses pembelajaran lebih efektif.

4) Pembelajar menjelaskan kembali langkah-langkah membaca pemahaman yang baik dan benar.

5) Pembelajar membentuk tempat duduk yang sebelumnya secara kelompok menjadi secara individu.

Sesuai perbaikan diatas pada siklus II telah terlaksana dan memperoleh hasil sebagai berikut:

1. Tes pebelajar yang tuntas dalam membaca pemahaman dengan menerapkan metode Snowball Throwing mengalami peningkatan dengan diperoleh 34 pebelajar, dengan persentase sebagai berikut:

$$
\frac{34}{36} \times 100 \%=94,44 \%
$$

Dengan jumlah pebelajar yang tuntas sebanyak 31 pebelajar dengan dibagi seluruh jumlah pebelajar sebanyak 36 dan dikalikan lagi 100\%, maka persentase jumlah pebelajar yang tuntas $94,44 \%$. Jadi kemampuan membaca pemahaman dengan metode Snowball Throwing pada kelas VII-E melebihi $50 \%$ atau sangat memuaskan.

2. Tes pebelajar yang tidak tuntas dalam membaca pemahaman dengan menerapkan metode Snowball Throwing diperoleh 2 pebelajar, dengan persentase sebagai berikut:

$$
\frac{2}{36} \times 100 \%=5,55 \%
$$

Dengan jumlah pebelajar yang tuntas sebanyak 5 pebelajar dengan dibagi seluruh jumlah pebelajar sebanyak 36 dan dikalikan lagi $100 \%$, maka persentase jumlah pebelajar yang tidak tuntas hanya 5,55\%. Jadi kemampuan membaca pemahaman dengan metode Snowball Throwing pada kelas VII-E yang tidak tuntas di bawah 50\%, sehingga dapat dikatakan penerapan metode Snowball Throwing dalam membaca pemahaman pebelajar kelas VII-E tidak banyak, sehingga memenuhi kriteria dengan hasil yang diharapkan.

Berdasarkan keterangan di atas maka lebih spesifik tertera pada grafik di bawah ini: 
Grafik 2. Hasil Tes Pebelajar VII-E SMPN 3 Waru pada Siklus II.

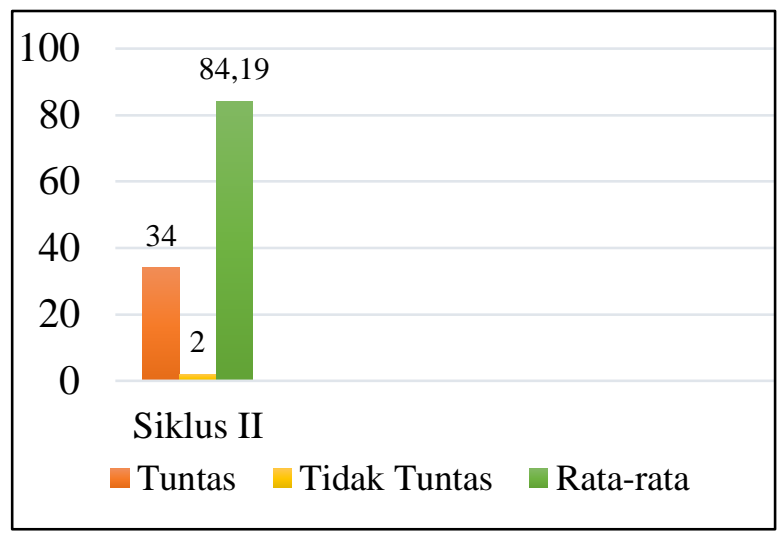

Grafik di atas dapat dijelaskan bahwa perolehan nilai pada siklus II sebagian besar pebelajar sudah mencapai SKL sesuai yang diinginkan. Pada grafik warna orange menunjukkan pebelajar yang tuntas atau mencapai SKL 34 pebelajar dengan persentase $94,44 \%$, grafik warna kuning menunjukkan pebelajar yang belum tuntas atau belum mencapai SKL sebanyak 2 pebelajar dengan persentase $5,55 \%$, dan grafik warna hijau menunjukkan nilai rata-rata kelas sebesar 84,19.

\section{PEMBAHASAN}

Pembahasan ini terfokus pada hasil prasiklus/ kondisi awal, siklus I, dan sklus II. Berdasarkan hasil refleksi awal diketahui kemampuan membaca pemahaman pebelajar masih kurang. Hal ini dapat diketahui dari rata-rata tingkat kemampuan membaca pemahaman mencapai 50,11 dan hanya 3 dari 36 pebelajar dengan persentase $8,33 \%$ yang mampu membaca pemahaman dengan baik. Sedangkan pebelajar yang tidak tuntas mencapai 33 dari 36 pebelajar dengan persentase 91,67\%. Dari hasil tersebut peneliti merancang tindakan untuk mempersiapkan perangkat pembelajaran dan mengadakan siklus I.

Setelah pembelajar memberi tindakan berupa metode Snowball Throwing pada siklus I, menunjukkan peningkatan kemampuan membaca pemahaman khususnya pada teks eksposisi. Dari siklus I dapat diketahui: (1) Aktivitas pebelajar Pebelajar yang mencapai SKL (80) sebanyak 10 pebelajar dengan persentase $27,78 \%$, sedangkan pebelajar yang belum mencapai SKL (80) sebanyak 26 dari 36 pebelajar dengan persentase 72,22\%; (2) Rata-rata kemampuan pebelajar dalam menemukan ide pokok dengan tepat sebesar 20,80 dengan kriteria cukup; (3) Rata-rata kemampuan pebelajar dalam memahami isi bacaan sebesar 21,80 dengan kriteria cukup; (4) Rata-rata kemampuan pebelajar dalam menceritakan kembali isi bacaan dengan bahasa sendiri sebesar 32,17 dengan kriteria baik; (5) Rata-rata skor kumulatif seluruh aspek mencapai 74,78 dengan kriteria cukup baik. Pada siklus I terdapat juga penilaian aktivitas pembelajar, menunjukkan aktivitas yang muncul sebesar 15 dari 18 aktivitas dengan persentase $83,3 \%$, sedangkan aktivitas pembelajar yang tidak muncul sebesar 3 dari 18 aktivitas dengan persentase 16,7\%.

Di bawah ini menerangkan secara rincih kemampuan pebelajar dalam membaca pemahaman yang meliputi aspek: (1) Menemukan ide pokok dengan tepat; (2) Memahami isi bacaan pada teks ekksposisi; (3) Menceritakan kembali 
isi bacaan dengan bahasa sendiri. Berikut tabel penilaian setiap aspek pada siklus I.

Tabel 1. Hasil Penilaian Setiap Aspek dalam Kemampuan Membaca Pemahaman dengan Metode Snowball Throwing pada Siklus I

\begin{tabular}{|l|c|c|c|c|}
\hline \multirow{2}{*}{ Aspek Penilaian } & \multicolumn{3}{|c|}{ Jumlah Pebelajar } \\
\cline { 2 - 5 } & $\begin{array}{c}\text { A (sangat } \\
\text { baik) }\end{array}$ & B (baik) & C (cukup) & $\begin{array}{c}\text { D } \\
\text { (kurang) }\end{array}$ \\
\hline 1. Menemukan ide pokok & $6(16,67 \%)$ & $\begin{array}{c}14 \\
(38,89 \%)\end{array}$ & $\begin{array}{c}14 \\
(38,89 \%)\end{array}$ & $\begin{array}{c}2(5,56 \\
\%)\end{array}$ \\
\hline 2. Memahami isi & $\begin{array}{c}10 \\
(27,78 \%)\end{array}$ & $\begin{array}{c}14 \\
(38,89 \%)\end{array}$ & $\begin{array}{c}13 \\
(36,11 \%)\end{array}$ & - \\
\hline $\begin{array}{c}\text { 3. Menceri-takan kembali isi } \\
\text { bacaan }\end{array}$ & $\begin{array}{c}35 \\
(97,22 \%)\end{array}$ & $1(2,78 \%)$ & - & - \\
\hline
\end{tabular}

Tabel diatas menunjukkan aspek yang paling menonjol yakni aspek menceritakan kembali isi bacaan dengan jumlah pebelajar 35 atau 97,22\%, karena sebelum diadakan penelitian pembelajar selalu menugasi pebelajar untuk aktif menulis beberapa paragraph sesuai dengan tujuan Kurikulum 2013.

Peningkatan yang signifikan juga terjadi pada pebelajar baik aktivitas yang dilakukan dan hasil tes yang telah ditetapkan oleh pembelajar. Pada aktivitas pebelajar diperoleh hasil sebagai berikut: (1) Pebelajar yang tuntas dan mencapai SKL sebanyak 34 dari 36 pebelajar dengan persentase 94,44\%, sedangkan pebelajar yang belum tuntas dan belum mencapai SKL sebanyak 2 pebelajar dengan persentase 5,55\%; (2) Rata-rata kemampuan pebelajar dalam menemukan ide pokok dengan tepat mengalami peningkatan 4,56 sebelumnya 20,80 menjadi 25,36 dengan kriteria baik; (3) Rata-rata kemampuan pebelajar dalam memahami isi bacaan meningkat 3,64 sebelumnya 21,80 pada siklus II menjadi 25,44 dengan kriteria baik; (4) Rata-rata kemampuan pebelajar dalam menceritakan kembali isi bacaan dengan bahasa sendiri sebesar 32,17 dengan kriteria baik; (5) Rata-rata skor kumulatif seluruh aspek meningkat 9,41 pada siklus I 74,78 menjadi 84,19 dengan kriteria cukup baik.

Tabel 1. Hasil Penilaian Setiap Aspek dalam Kemampuan Membaca Pemahaman dengan Metode Snowball Throwing pada Siklus II.

\begin{tabular}{|l|c|c|c|c|}
\hline \multirow{2}{*}{\multicolumn{1}{|c|}{ Aspek Penilaian }} & \multicolumn{3}{|c|}{ Jumlah Pebelajar } \\
\cline { 2 - 5 } & $\begin{array}{c}\text { A (sangat } \\
\text { baik) }\end{array}$ & B (baik) & C (cukup) & $\begin{array}{c}\text { D } \\
\text { (kurang) }\end{array}$ \\
\hline 1. Menemukan ide pokok & $\begin{array}{c}24 \\
(66,67 \%)\end{array}$ & $\begin{array}{c}12 \\
(33,33 \%)\end{array}$ & - & - \\
\hline 2. Memahami isi & $\begin{array}{c}26 \\
(72,22 \%)\end{array}$ & $9(25 \%)$ & 1 & - \\
\hline $\begin{array}{c}\text { 3. Menceri-takan kembali isi } \\
\text { bacaan }\end{array}$ & $36(100 \%)$ & - & - & - \\
\hline
\end{tabular}


Dari hasil tabel diatas kemampuan membaca pemahaman pebelajar mengalami peningkatan dan sebagian besar pebelajar meraih nilai A pada setiap aspek yang ditentukan.

\section{SIMPULAN}

Hasil kondisi awal/ prasiklus dapat diketahui tingkat kemampuan pebelajar dalam membuat dan menjawab pertanyaan masih kurang memperhatikan konteks bacaan. Hasil perolehan nilai ketuntasan pada prasiklus yakni $8,32 \%$ dengan ratarata 50,11 .

Hasil siklus I dapat diketahui: (1) Aktivitas pembelajar yang terlaksana sebesar 83,3\%; (2) Aktivitas pebelajar yang muncul sebesar 85,4\%; (3) Hasil tes kemampuan membaca pemahaman pebelajar yang tuntas sebesar $27,78 \%$ dengan rata-rata sebesar 74,78 .

Hasil siklus II dapat diketahui: (1) Aktivitas pembelajar telah terlaksana semua meningkat 16,7\% dengan hasil sebesar 100\%; (2) Aktivitas pebelajar yang muncul juga meningkat 6,96\% menjadi 92,36\%; (3) Hasil tes kemampuan membaca pemahaman pebelajar yang tuntas atau sesuai SKL sebesar 94,44\% meningkat $66,66 \%$. Sedangkan rata-rata pebelajar dalam membaca pemahaman juga meningkat 9,41\% menjadi 84,19.

Hasil dari penelitian dan pembahasan dengan penerapan metode Snowball Throwing terbukti dapat meningkatkan kemampuan membaca pemahaman siswa kelas VII-E SMP Negeri 3 Waru Sidoarjo tahun ajaran 2014/2015 telah berhasil mencapai nilai yang memuaskan dan melebihi nilai Standart Kompetensi Lulusan (SKL) sebesar 80.

\section{SARAN}

Berdasarkan hasil penelitian tersebut dapat dikemukakan saran sebagai berikut:

1. Kepala Sekolah

Sekolah mendukung dan mengembangkan penerapan pembelajaran inovatif dan kreatif yaitu penerapan metode snowball throwing pada membaca pemahaman, serta mengadakan acara seminar atau diklat bagi guru mata pelajaran lain agar lebih semangat dalam mendidik siswa dengan pembelajaran yang inovatif dan kreatif.

2. Guru mata pelajaran

Guru dapat menerapkan metode snowball throwing untuk mempengaruhi siswa dalam membaca pemahaman agar siswa mengetahui keuntungan membaca pemahaman khususnya pada materi pelajaran dan menghimbau siswa agar gemar membaca. Serta lebih aktif untuk menggunakan metode pembelajaran yang lain.

3. Siswa

Lebih meningkatkan kemampuan membaca dan dapat mengelolah perbendaharaan kata. Dengan gemar membaca dapat dikuasai kata/ kalimat yang efektif serta dapat menghasilkan tulisan yang benar. 


\section{DAFTAR PUSTAKA}

Budiono, Sunu Catur,. dkk. 2012. Pedoman Penulisan Skripsi dan Artikel Ilmiah. Surabaya: Fakultas Kepembelajaran dan Ilmu Pendidikan Universitas PGRI Adi Buana Surabaya.

Huda, Miftahul. 2013. Model-model Pengajaran dan Pembelajaran: Isu-isu Metodis dan Paradigmatis. Pustaka Pelajar: Yogyakarta.

Iskandarwassid dan Dadang Sunendar. 2011. Strategi Pembelajaran Bahasa. Remaja Rosdakarya: Bandung.

Indarti, Titik. 2008. Penelitian Tindakan Kelas (PTK) dan Penulisan Ilmiah. Surabaya: FBS Unesa.

Nurhadi. 2010. Membaca Cepat dan Efektif. Sinar Baru Algensindo: Bandung.

Nurhadi. 2010. Bagaimana Meningkatkan Kemampuan Membaca: Suatu Teknik Memahami Literatur yang Efisien. Sinar Baru Algensindo: Bandung.

Tarigan H. Guntur. 2008. Membaca: Sebagai Suatu Keterampilan Berbahasa. Angkasa: Bandung.

Taniredja, Tukiran, Irma Pujiati, dan Nyata. 2012. Penelitian Tindakan Kelas Untuk Pengembangan Profesi Pembelajar. Bandung: Alfabeta.

Wahana, Pengetahuan. 2013. Bahasa Indonesia Ekspresi Diri dan Akademik SMP/MTS. Jakarta: Kemendikbud.

Azizah, N. Siti. 2013. Meningkatkan Kemampuan Membaca Cepat pada Pebelajar Kelas VII E SMP Praja Mukti Surabaya Tahun Pelajaran 2012-2013 Melalui Kissnowbath. Skripsi. Surabaya: Universitas PGRI Adi Buana Surabaya.

Ebook: Speed Reading for Beginners (Panduan Membaca Lebih Cepat, Lebih Cerdas, dan Pemahaman yang Lebih Baik). Edisi Bahasa Indonesia. Oleh Muhammad Noer (www.MuhammadNoer.com). Diakses atau di unduh pada tanggal 19 Juli 2014 pukul 12.29 .

Abdulloh. 2013. Keterampilan Membaca: Membaca Pemahaman. Tersedia pada http://abdullohaja.blogspot.com/2013/01/ keterampilan-membaca-

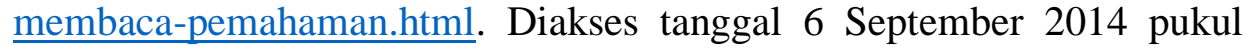
15.36

Awax Badan. Membaca Pemahaman Menurut Ahli. http://kumpulan-contohptk.blogspot.com/2013/07/pengertian-membaca-pemahamanmenurut.html. Diakses pada tanggal 10 September 2014 pukul 17.00 
Faizal Nisbah. 2013. Pengertian Membaca Pemahaman. http://faizalnizbah.blogspot.com/2013/08/pengertian-membacapemahaman.html. Diakses tanggal 10 September 2014 pukul 16.52

Muhammad Anshari. 2013. Model Pembelajaran Snowball Throwing. Tersedia pada http://muhammadanshari9.blogspot.com/2013/10/ modelpembelajaran-snowball-throwing.html. Diakses pada tanggal 08 Agustus 2014 pukul 08.00.

Nur Khosun. 2011. Hakikat Membaca Pemahaman. Tersedia pada http://nurkhosun.blogspot.com/2011/05/hakikat-membacapemahaman.html. Diakses tanggal 10 September 2014 pukul 15.36.

Suluh. 2010. Membaca Pemahaman. Tersedia pada http://suluhpendidikan. blogspot.com/2010/06/membaca-pemahaman.html Diakses tanggal 6 September 2014 pukul 15.16 . 